\title{
Comparison of resistance to damage of unalloyed carbon steels under the influence of hydrogen
}

\author{
Izabela Pietkun-Greber* \\ University of Opole, Independent Department of Process Engineering, Dmowskiego 7-9, 45-365 \\ Opole, Poland
}

\begin{abstract}
One of the most commonly used construction material in industry is unalloyed steel S235 and S355. These types of steel are used for construction of ships, bridges, coastal construction, welded tanks, and in buildings. Due to the operating conditions, these types of steel may undergo hydrogen degradation in the process of manufacturing of welded structures or when operating the structures. This paper presents the results of study into resistance of selected types of non-alloy structural steels to hydrogen degradation. Tests were carried out to determine changes in mechanical properties in the static trials of stretching without hydrogen, and after saturation with hydrogen. Parallel fractographic and electrochemical studies were carried out. Hydrogen saturation was carried out at the time from 3. up to 24 . hours in a solution of $0.1 \mathrm{~N} \mathrm{H}_{2} \mathrm{SO}_{4}$ with the addition of $2 \mathrm{mg} / \mathrm{dm}^{3}$ arsenic oxide (III) at an electric current density of 20 $\mathrm{mA} / \mathrm{cm}^{2}$. The results of the tests have shown that the impact of hydrogen on the tested steels S235JR and S355J2 leads to a significant deterioration in their mechanical and electrochemical properties. At comparable concentrations of hydrogen, steel S235JR is less susceptible to hydrogen degradation and has greater corrosive resistance measured in $3 \% \mathrm{NaCl}$ solution, in comparison with steel S355J2.
\end{abstract}

\section{Introduction}

Hydrogen is the only element capable of diffusion at room temperature and desorption at temperatures above $100^{\circ} \mathrm{C}$. The effects of its destructive activity can be observed both in steels, alloys, composites, and in connections performed using various methods [1]. Hydrogen charging of materials leads to significant deterioration not only in their mechanical, physical and electrochemical properties, but also, in extreme cases, it can cause structural damage, and even be the cause of major accidents.

Hydrogen degradation of materials includes all processes resulting from the presence of hydrogen in their structure. Hydrogen degradation is determined by several processes, namely adsorption and absorption (hydrogen charging), diffusion (transportation of

\footnotetext{
*Corresponding author: ipietkun@uni.opole.pl
} 
hydrogen in steel), and location of hydrogen in steel (trapping) [2]. The processes of sorption, transportation and trapping of hydrogen in a material of a certain level of stress and strain, which take place in a continuous way, contribute to its total destruction. Hydrogen degradation takes different forms, depending on the type of material, environment, temperature and mechanical loads. In metallic materials it may result in delayed cracking, deterioration of plastic properties $[3,4,5]$, decarbonisation, delamination, or hydrogen blistering filled with molecular hydrogen $[6,7,8]$.

The intensity of material degradation due to charging with hydrogen depends largely on the ability to dissolve and on the speed of diffusion of hydrogen in the given metal (steel). Studies have shown that austenitic steels show much lower diffusion rate than ferritic, martensitic, and those of mixed structure $[9,10,11]$. Kinetics of the diffusion process is complicated by the phenomena related to structural changes, including the formation of hydrides.

The subject literature offers numerous models describing the mechanism of hydrogen degradation, which means that there is no one universal mechanism describing and explaining all the cases (forms) of hydrogen degradation, and the effect of all factors on hydrogen degradation. Sometimes in one and the same material degradation powered by hydrogen can develop by several mechanisms. The most probable mechanisms of hydrogen degradation are: dislocation, internal pressure, network decohesion, adsorption, and the hydride phases [12-15].

To assess the degree of hydrogen degradation, next to the basic mechanical criterion based on degradation of mechanical properties, structural criteria are also used, in which the key role is played by the changes caused by the presence of hydrogen in the microstructure and on the surface of the fractures. Obtained as a result of the study, stress-strain curves (SSRT, static tensile test) in conjunction with the fractures analysis by the quantitative fractography method lead to a more complete characteristics of the phenomenon of degradation of the alloys in corrosive environments [3]. Different concentrations of hydrogen not only reflect on the surface of the fractures after a static tensile test (change in the nature the fractures) [16-17], but also in the deterioration of the corrosive properties [6, 18-20]. To assess the degree of hydrogen degradation in materials also non-destructive methods are used. Ultrasonic examinations are ideally suited for monitoring of delamination of petrochemical installations after hydrogen attack [21].

The unalloyed steels S235 and S355 are commonly used construction materials in industry. These types of steel are used for construction of ships, bridges, coastal construction, welded tanks, pressure pipes, and parts and components working in low temperatures. Due to the conditions of use, these types of steel may undergo hydrogen degradation in the course of manufacturing of welded structures (in the form of cold cracks) or the operation of the structure (in the form of hydrogen induced cracks HIC).

The aim of this paper is to compare the degree of susceptibility to hydrogen degradation of selected unalloyed structural steels depending on the conditions of cathodic polarization.

\section{Research material and methodology}

\subsection{Material}

The test material was metal sheet $2.0 \mathrm{~mm}$ thick, of S235JR and S355J2 steel. The results of the chemical analysis control test of steel carried out on optical spectrometer and the required content elements for both steel grades according to PN-EN 10025-2 [22] are summarized in table 1 . 
Tabela 1. The chemical composition of the tested steels.

\begin{tabular}{|l|c|c|c|c|c|c|c|c|c|}
\hline \multirow{2}{*}{ Steel } & \multicolumn{10}{c|}{ Chemical elements [wt.\%] } \\
\cline { 2 - 9 } & $\mathbf{C}$ & Mn & Si & P & S & Cu & Cr & Ni & Fe \\
\hline \multicolumn{8}{|c|}{ PN-EN 10025-2 } \\
\hline S235JR & 0.17 & 1.40 & - & 0.025 & 0.025 & 0.55 & - & - & rest. \\
\hline S355J2 & 0.20 & 1.60 & 0.55 & 0.025 & 0.025 & 0.55 & - & - & rest. \\
\hline \multicolumn{8}{|c|}{ Spectra analysis } \\
\hline S235JR & 0.13 & 0.98 & 0.01 & 0.013 & 0.015 & 0.02 & 0.03 & 0.02 & rest. \\
\hline S355J2 & 0.18 & 1.21 & 0.24 & 0.014 & 0.007 & 0.03 & 0.02 & 0.01 & rest. \\
\hline
\end{tabular}

\subsection{The conditions of cathodic polarization and the determination of hydrogen content}

The cathodic polarization of the steel samples was carried out in a solution of $0.1 \mathrm{~N}$ $\mathrm{H}_{2} \mathrm{SO}_{4}$ containing an addition of $2 \mathrm{mg} / \mathrm{dm}^{3}$ of arsenic oxide (III). $20 \mathrm{~mA} / \mathrm{cm}^{2}$ density current was applied for the time of 3. up to 24 . hours. The amount of hydrogen in the test samples of steel before and after the polarisation were marked in ppm by using the LECO ONH836 analyser. During the test, the sample was melted and all forms of hydrogen (diffusion hydrogen, hydrogen trapped reversibly and irreversibly) were released. The results obtained showed the total concentration of hydrogen, i.e. diffusion and trapped hydrogen. Measurement of hydrogen content in steel was made on three samples: without charging, and after charging with hydrogen. Due to the possibility of desorption of hydrogen from the alloy, the samples were stored in liquid nitrogen until the analysis of its concentration in the material.

\subsection{The influence of hydrogen charging parameters on the mechanical properties of the samples}

To estimate the susceptibility of the tested steel to hydrogen degradation, a static stretching test was applied. The samples were flat, with an initial length of $50 \mathrm{~mm}$ and a cross-section of $2 \times 12.55 \mathrm{~mm}$ in accordance with PN-EN ISO 6892-1 [23]. The samples were hydrogen saturated without additional external stresses. Various times of saturation were applied in order to obtain samples of varying degrees of degradation. Due to the significant impact of hydrogen desorption process in alloys on the results of tests of mechanical properties (change in hydrogen concentration), the tensile test was carried out directly after charging. The measurements were performed at $21 \div 23^{\circ} \mathrm{C}$. In all cases, tests were carried out on three samples to characterize the state of the material without charging and after charging with hydrogen.

\subsection{Microscopic observations}

The fractures of steel samples resulting from static tensile tests were purified from the contaminants in an ultrasound bath in acetone over the time of 5 minutes. The prepared fracture surfaces were observed using a scanning electron microscope Hitachi S-3400N. Thermo Scientific software was used for image recording. 


\subsection{Electrochemical research}

The measuring system used consisted of a measuring vessel, AMEL PSW01 5000 System potentiometer, and a computer with CorrWare software. The auxiliary electrode was made of platinum, and a calomel saturated electrode (NEK) was used as a reference electrode. $3 \%$ aqueous solution of $\mathrm{NaCl}$ was used for the tests. Depending on the type of testing, the work electrodes (WE) used were respectively non-hydrogenated and hydrogenated steel samples. The test samples were sanded with water sandpaper of 1200 grit, and then thoroughly rinsed with distilled water, avoiding greasing the sanded surfaces. The sanded samples were purified in ethanol with an ultrasonic washer, rinsed with distilled water, and dried with blotting paper. The prepared samples, depending on the type of test, were placed directly in the electrochemical vessel or in an electrolyser in order to saturate them with hydrogen. Before the polarization measurements, the open circuit potential (EOCP) measurements were carried out in order to determine the initial value of the corrosion potential $\left(\mathrm{E}_{\text {corr }}\right)$. Polarisation of the samples was carried out at a potential scanning rate of $\mathrm{dE} / \mathrm{dt}=1 \mathrm{mV} / \mathrm{s}$ within $\pm 300 \mathrm{mV}$ of the value of the open circuit potential. Corrosion current density value $\left(\mathrm{I}_{\text {corr }}\right)$, corrosion potential $\left(\mathrm{E}_{\text {corr }}\right)$ and the polarization resistance $\left(R_{p}\right)$ were determined by Stern method.

\section{Results and discussion}

The determined hydrogen content in the steels tested in the state of delivery were $1.50 \mathrm{ppm}$ for the S235JR steel, and $2.06 \mathrm{ppm}$ for the S355J2 steel. For the tested steels along with the increase of cathodic polarisation time, the concentration of the sorbed hydrogen increased (table 2). In samples of steel S235JR undergoing cathodic polarization which lasted 3 hours, hydrogen concentration was $7.92 \mathrm{ppm}$. Comparable concentration of hydrogen was marked in the samples of steel S355J2 after polarization which lasted 12 hours. The difference in the amount of the absorbed hydrogen by the tested steels is connected with their chemical composition and micro-structure.

The tests of mechanical properties of the steels were carried out in a longitudinal direction. Figure 1 shows the stress-strain curves obtained as a result of the carried out trial of static stretching of the tested steel before and after charging with hydrogen. Tables 2-3 summarize the detailed quantitative values that characterize the properties of strength and plasticity.

a)

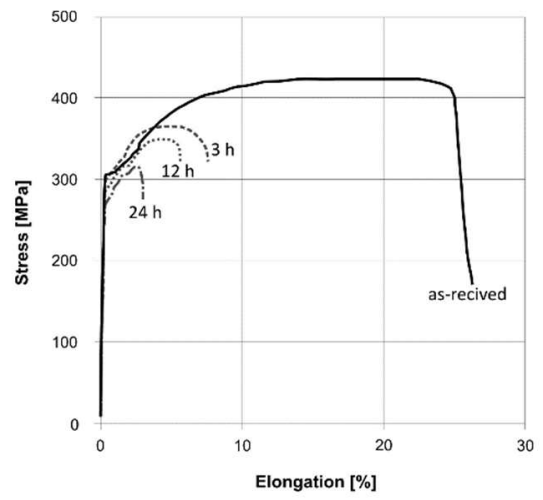

b)

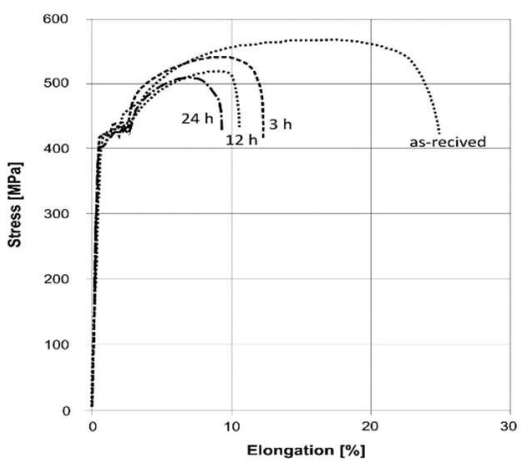

Fig. 1. Stress-elongation curves before and after hydrogenation: a) S235JR, b) S355J2. 
Table 2. Mechanical properties of S235JR tested before and after hydrogenation.

\begin{tabular}{|l|c|c|c|c|c|}
\hline $\begin{array}{l}\text { Hydrogenation time, } \mathbf{h} \\
\text { (hydrogen concentration, ppm) }\end{array}$ & $\begin{array}{c}\mathbf{R}_{\mathbf{m}}, \\
\mathbf{M P a}\end{array}$ & $\begin{array}{c}\mathbf{R}_{\mathbf{p 0 . 2}}, \\
\mathbf{M P a}\end{array}$ & $\begin{array}{c}\mathbf{A 5 0 m m}, \\
\mathbf{\%}\end{array}$ & $\begin{array}{c}\mathbf{Z}, \\
\mathbf{\%}\end{array}$ & $\begin{array}{c}\text { HEI, } \\
\mathbf{\%}\end{array}$ \\
\hline as-received (1.50) & 425 & 324 & 26.4 & 45.0 & - \\
\hline 3 hours (7.92) & 358 & 298 & 7.8 & 16.7 & 63 \\
\hline 12 hours (10.30) & 344 & 280 & 5.8 & 9.4 & 79 \\
\hline 24 hours (13.33) & 316 & 275 & 3.2 & 4.1 & 91 \\
\hline
\end{tabular}

Table 3. Mechanical properties of S355J2 tested before and after hydrogenation.

\begin{tabular}{|l|c|c|c|c|c|}
\hline $\begin{array}{l}\text { Hydrogenation time, } \mathbf{h} \\
\text { (hydrogen concentration, ppm) }\end{array}$ & $\begin{array}{c}\mathbf{R}_{\mathbf{m}}, \\
\mathbf{M P a}\end{array}$ & $\begin{array}{c}\mathbf{R}_{\mathbf{p 0 . 2}}, \\
\mathbf{M P a}\end{array}$ & $\begin{array}{c}\mathbf{A}_{\mathbf{5 0 m m}}, \\
\mathbf{\%}\end{array}$ & $\begin{array}{c}\mathbf{Z}, \\
\mathbf{\%}\end{array}$ & $\begin{array}{c}\text { HEI, } \\
\mathbf{\%}\end{array}$ \\
\hline as-received (2.08) & 569 & 429 & 25.2 & 43.5 & - \\
\hline 3 hours (6.58) & 534 & 419 & 12.0 & 17.3 & 60 \\
\hline 12 hours (7.25) & 517 & 409 & 10.3 & 13.6 & 69 \\
\hline 24 hours (8.37) & 513 & 405 & 8.7 & 9.1 & 79 \\
\hline
\end{tabular}

On the basis of the experimental data a distinct change in mechanical properties of the tested steels along with the change of the conditions of cathodic polarization can be noted (tables 2 and 3). Strength properties of steel S235JR clearly deteriorated - decrease in tensile strength $\left(\mathrm{R}_{\mathrm{m}}\right)$ from $425 \mathrm{MPa}$ to $316 \mathrm{MPa}$, and yield strength $\left(\mathrm{R}_{\mathrm{p} 0.2}\right)$ from $324 \mathrm{MPa}$ to $275 \mathrm{MPa}$. Plastic properties of the tested steel also deteriorated - decrease of elongation from $26.4 \%$ to $3.2 \%$, and reduction of area from $45.0 \%$ to $4.1 \%$. Hydrogen brittleness index HEI of the steels ranged from $63 \%$ to $91 \%$ depending on the time of hydrogen charging. Analysis of the tests results of mechanical properties of S355J2 steel after hydrogen charging, showed that tensile strength $\left(\mathrm{R}_{\mathrm{m}}\right)$ decreased with increased hydrogen content in steel from $569 \mathrm{MPa}$ to $513 \mathrm{MPa}$. Yield strength was reduced from $429 \mathrm{MPa}$ to $405 \mathrm{MPa}$. Analysis of stress-strain curves (fig. 1) showed that electrolytic hydrogen charging decreases elongation percentage. Elongation of steel was reduced about 2 times at hydrogen content of $6.58 \mathrm{ppm}$, and about 3 times when the time of polarization was increased up to 24 hours. Hydrogen brittleness index HEI of S355J2 steel ranged from $60 \%$ to $79 \%$ depending on the conditions of cathodic polarisation.

Observation of the fracture surfaces obtained from the static tensile test showed differences in morphology (fig. 2-4). In the case of non-hydrogen charged steel samples, the fracture surfaces were characterised by morphology typical of fractures of a plastic nature (fig. 3). Cracking occurred in a plane perpendicular to the direction of maximum tensile stress. In samples of steel subjected to the impact of hydrogen, a change in the nature of cracking was noted. Samples of both steels subjected to cathodic polarization which lasted 12 hours, had transcristalline fractures with numerous cracks (fig. 3). Increase in the time of polarisation to 24 . hours resulted in an increase in hydrogen content in both tested steels, which contributed to the increase in the number of cracks (fig. 4). 
a)

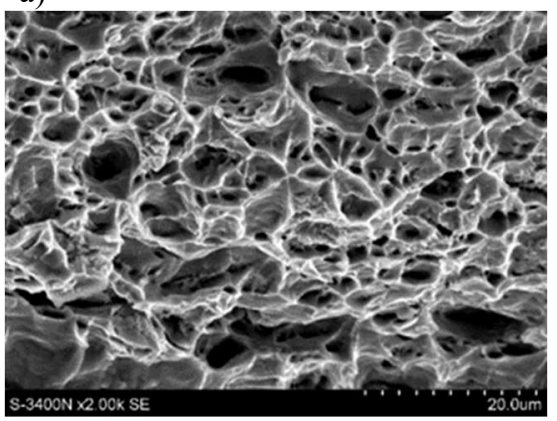

b)

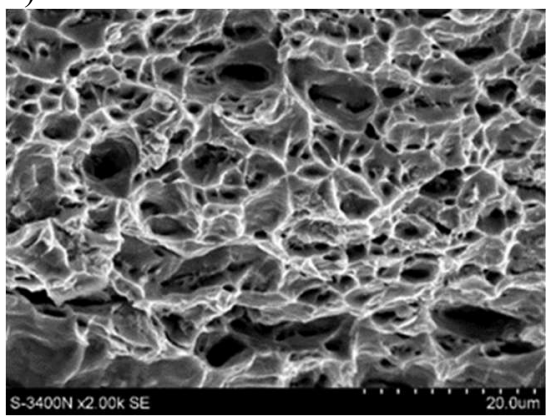

Fig. 2. Morphology of the surface of a fracture after a stretching trial without the impact of hydrogen: a) steel S235JR, b) steel S355J2.

a)

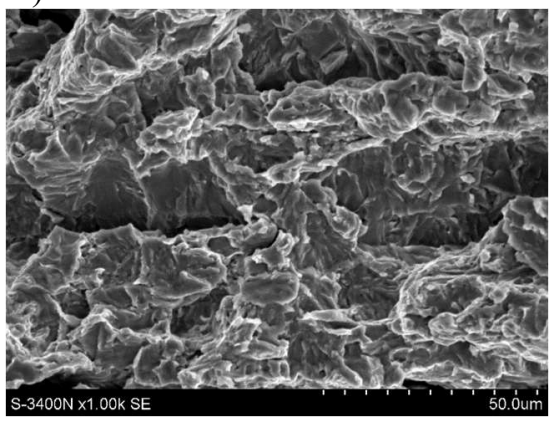

b)

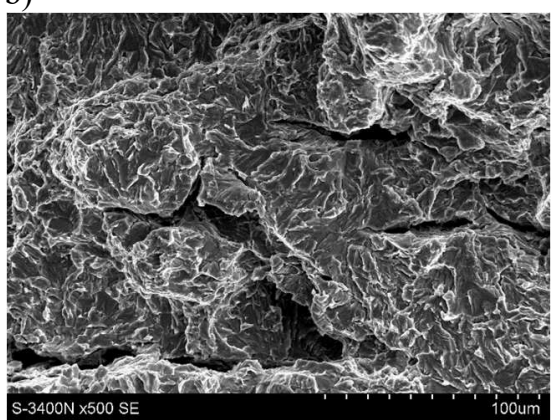

Fig. 3. Morfology of the surfaces of a fracture samples of steel hydrogenated for 12 hours and stretched: a) S235JR, b) S355J2.

a)

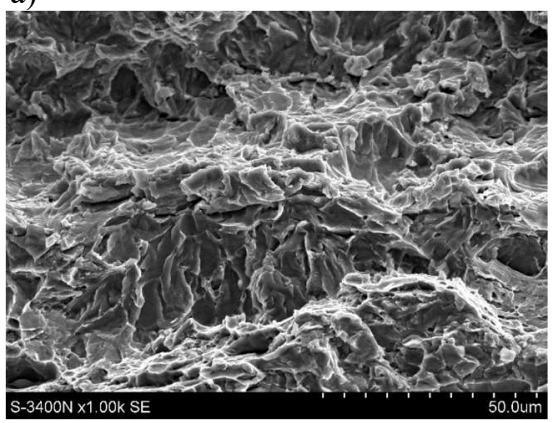

b)

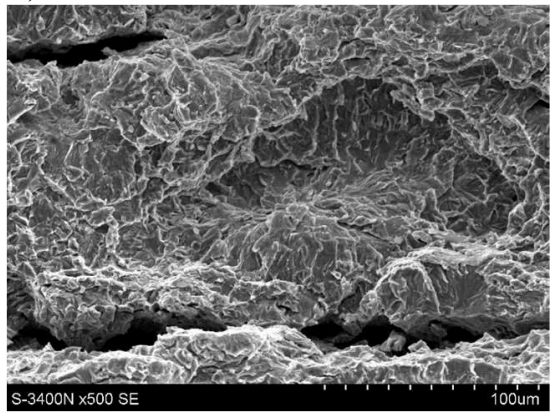

Fig. 4. Morfology of the surfaces of a fracture samples of steel hydrogenated for 24 hours and stretched: a) S235JR, b) S355J2.

Tables 4 and 5 present the results, i.e. the average of three measurements of electrochemical parameters of the tested steels, measured in $3 \% \mathrm{NaCl}$ solution. Changes in the value of the steel potential as a function of time depending on the parameters of the electrolytic hydrogen charging are shown in fig. 5-6. Figures 7-8 present the courses of the tested potentiodynamic curves of the non-hydrogen-charged steels, after cathodic polarization. 
Table 4. The electrochemical parameters of the tested steel S235JR.

\begin{tabular}{|l|c|c|c|c|}
\hline $\begin{array}{l}\text { Hydrogenation time, } \mathbf{h} \\
\text { (Hydrogen concentration, } \mathbf{p p m})\end{array}$ & $\begin{array}{c}\mathbf{E} \text { ocP } \\
{[\mathbf{m V}]}\end{array}$ & $\begin{array}{c}\mathbf{E}_{\mathbf{c o r r}} \\
{[\mathbf{m V}]}\end{array}$ & $\begin{array}{c}\mathbf{I}_{\mathbf{c o r r}} \\
{\left[\boldsymbol{\mu} \mathbf{A} / \mathbf{c m}^{\mathbf{2}}\right]}\end{array}$ & $\begin{array}{c}\mathbf{R}_{\mathbf{p}} \\
{\left[\mathbf{k} \boldsymbol{\Omega} / \mathbf{c m}^{2}\right]}\end{array}$ \\
\hline as-received (1.50) & -606 & -507 & 13.90 & 1.88 \\
\hline 3 hours (7.92) & -624 & -592 & 16.30 & 1.54 \\
\hline 12 hours (10.30) & -628 & -610 & 18.07 & 1.32 \\
\hline 24 hours (13.33) & -678 & -698 & 23.58 & 1.11 \\
\hline
\end{tabular}

Table 5. The electrochemical parameters of the tested steel S355J2.

\begin{tabular}{|l|c|c|c|c|}
\hline $\begin{array}{l}\text { Hydrogenation time, } \mathbf{h} \\
\text { (Hydrogen concentration, } \mathbf{p p m})\end{array}$ & $\begin{array}{c}\text { EocP } \\
{[\mathbf{m V}]}\end{array}$ & $\begin{array}{c}\mathbf{E}_{\mathbf{c o r r}} \\
{[\mathbf{m V}]}\end{array}$ & $\begin{array}{c}\mathbf{I}_{\mathbf{c o r r}} \\
{\left[\boldsymbol{\mu} \mathbf{A} / \mathbf{c m}^{2}\right]}\end{array}$ & $\begin{array}{c}\mathbf{R}_{\mathbf{p}} \\
{\left[\mathbf{k} \boldsymbol{\Omega} / \mathbf{c m}^{2}\right]}\end{array}$ \\
\hline as-received (2.08) & -612 & -516 & 19.28 & 1.37 \\
\hline 3 hours (6.58) & -633 & -576 & 25.30 & 1.03 \\
\hline 12 hours (7.25) & -647 & -585 & 34.96 & 0.76 \\
\hline 24 hours (8.37) & -675 & -615 & 55.17 & 0.47 \\
\hline
\end{tabular}

The value of the steady potential ( $\mathrm{E}_{\mathrm{OCP}}$ ) of S235JR steel measured in $3 \% \mathrm{NaCl}$ was moving towards negative values with increasing amounts of hydrogen sorbed from the level of $-606 \mathrm{mV}$ (without the hydrogen charging) to $-678 \mathrm{mV}$ at hydrogen content of $13.33 \mathrm{ppm}$ (fig. 5). The steady-potential curves of time-potential, the tested samples of steel after the cathodic polarization for 3 , and for 12 hours initially observed a decline in the value of the potential, but then the value of the potential increased and stabilised after about 5000 . seconds depending on the time of hydrogen charging from $-619 \mathrm{mV}$ to $-628 \mathrm{mV}$. For the samples polarised for 24 hours, the value of the potential decreased along with the duration of the measurement. After the exposure of 5 hours, the value of the potential of the hydrogen-charged steel samples was $-678 \mathrm{mV}$. Differences in the changes in the value of the potentials with the passage of time are caused by different content of previously sorbed hydrogen, as well as the depth of penetration of hydrogen throughout the volume of the material, including by their surface layers and sub-surface, and the disorder level of these layers.

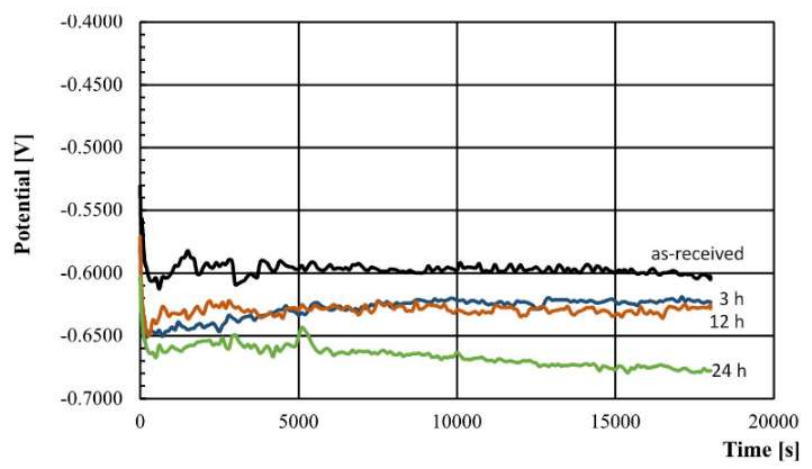

Fig. 5. The course of changes in the value of the potential of steel S235JR in $3 \% \mathrm{NaCl}$ solution.

After the analysis of changes in the value of the potential of the steel S355J2 measured in $3 \% \mathrm{NaCl}$, it appeared that changing the time of electrolytic hydrogen charging, as in the case of steel S235JR, causes a change in the value of its steady potential (EOCP) in $3 \% \mathrm{NaCl}$ (fig. 6). With the increase in the concentration of hydrogen in steel, the value of the 
potential has moved from the level of $-612 \mathrm{mV}$ (without the hydrogen-charging) to -675 $\mathrm{mV}$ for cathodic polarization which lasted 24 hours. The steady-potential curves of timepotential of the tested samples of steel after the cathodic polarization for 3, and for 12 hours, a decline in the value of the potential was initially observed, but then and value of the potential increased and stabilised after about 5000. seconds depending on the time of hydrogen charging from $-639 \mathrm{mV}$ to $-650 \mathrm{mV}$.

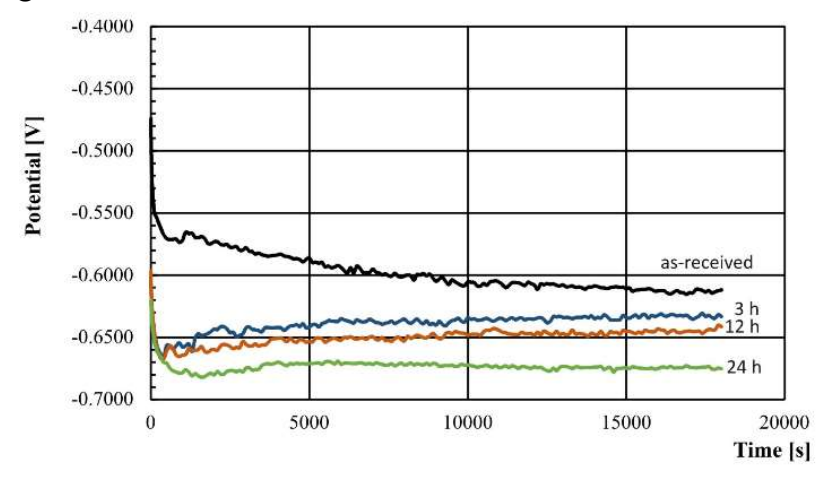

Fig. 6. The course of changes in the value of the potential of steel $\mathrm{S} 355 \mathrm{~J} 2$ in $3 \% \mathrm{NaCl}$ solution.

Measured in $3 \% \mathrm{NaCl}$ solution, the corrosion potential values $\left(\mathrm{E}_{\text {corr }}\right)$ for steel S235JR and $\mathrm{S} 355 \mathrm{~J} 2$ without hydrogen charging, were respectively $-507 \mathrm{mV}$, and $-516 \mathrm{mV}$. From the analysis of the data presented in table 4-5, and Fig. 7-8, it appears that the hydrogen sorbed by the steels changes the values of their corrosion potential $\left(\mathrm{E}_{\text {corr }}\right)$. On the potentiodynamic curves of the polarised, hydrogen-charged steel samples, the passive range was not observed. For the tested steels with the increase in the value of the potential, the value of the current density was increasing (tab. 4-5). The value of the potential of steel S235JR measured in $3 \% \mathrm{NaCl}$ solution, depending on the amount of the hydrogen sorbed during cathodic polarisation ranged from $-592 \mathrm{mV}$ to $-698 \mathrm{mV}$. In the case of steel S355J2, the recorded values of the potential were lower compared to steel S235JR and ranged from $-576 \mathrm{mV}$ to $-615 \mathrm{mV}$. For both steel grades, the decrease in polarization resistance was concurrent with an increase in the corrosion current density (fig. 7-8).

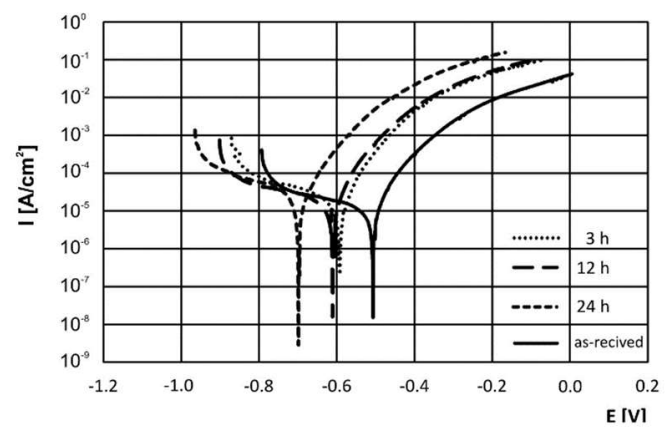

Rys. 7. Polarization curves of S235JR steel. 


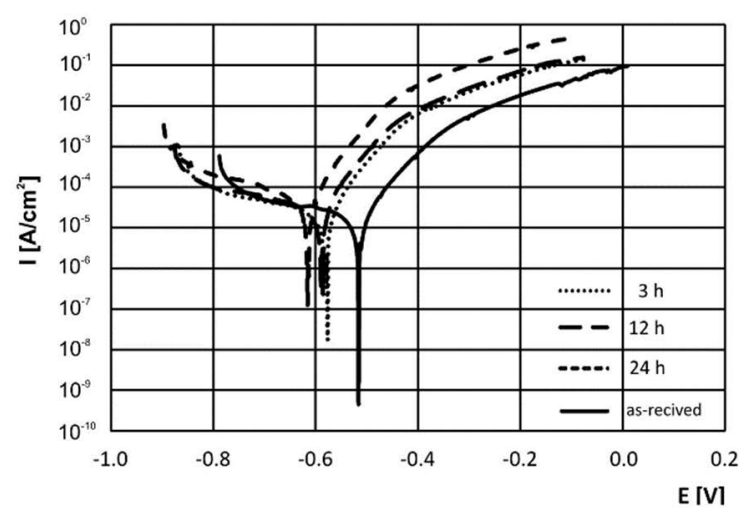

Rys. 8. Polarization curves of S355J2 steel.

The testing of electrochemical properties of the tested grades of steel by linear polarization method allowed to assess the impact of changes in the conditions of the cathodic polarization - the amount of hydrogen to the level of corrosive resistance in $3 \%$ $\mathrm{NaCl}$ solution. It was found that the time of its duration helps to change the corrosion resistance of the tested steels, measured in $3 \% \mathrm{NaCl}$ solution. The longer the time of hydrogen charging was, the lower was the corrosive resistance of steel in $3 \% \mathrm{NaCl}$ solution. The results of testing of corrosion resistance of the hydrogen-charged steels in $3 \%$ $\mathrm{NaCl}$ solution allowed to rank the steels by corrosion resistance. With hydrogen content at around $8 \mathrm{ppm}$, steel S235JR had greater corrosion resistance in $3 \% \mathrm{NaCl}$ solution compared to steel S355J2.

\section{Conclusions}

- The conditions of cathodic polarization have a significant impact on the amount of absorbed hydrogen by the tested steels. The concentration of hydrogen in the tested steels increases along with extension of time of cathodic polarization.

- The impact of hydrogen present in the tested steels leads to changes in their mechanical properties. Significantly deteriorated are plastic properties, i.e. reduction of area and elongation.

- The hydrogen sorbed by the tested steels affects negatively their corrosive properties. The longer the time of hydrogen charging, the lower the corrosive resistance of steel in $3 \% \mathrm{NaCl}$ solution.

- The mechanical and electrochemical properties of the tested steels after hydrogen charging, adopted as a criterion for assessment of resistance to hydrogen deterioration, allowed to compare the tested steels. At comparable concentrations of hydrogen, steel S235JR is less vulnerable to destruction in comparison with steel S355J2.

\section{References}

1. K. Lublińska, M. Gloc, M. Szwed, A. Zagórski, Ochr. przed kor. 11 (2010)

2. T. Lis, Metalurgia stali o wysokiej czystości (Wyd. Wydawnictwo Politechniki Śląskiej, Gliwice, 2009) 
3. M. Sozańska, A. Mościcki, B. Chmiela, Arch. Metall. Mater 62 (2017)

4. T. Hojo, Y. Ukai, Akiyama, Proc. Eng. 207 (2017)

5. Y. Liu, M. Wang, G. Liu, Mater. Sci. Eng. A, 594 (2014)

6. I. Pietkun-Greber, Ecolog. Chem. Eng. A, 23, 3 (2016)

7. D P. Dunne, D. Hejazi, A. A. Saleh, A. J. Haq, A. Calka, E. V. Pereloma, Inter. J of Hydrog Energ 41, 28 (2016)

8. A. A. Saleh, D. Hejazi, A. A. Gazder, D. P. Dunne, E. V. Pereloma, Intern. J of Hydrogen Energy, 41 (206)

9. H. J. Grabke, E. Riecke, Material in Technologije, 34, 6 (2000)

10. T. Mente, Th. Bollinghaus, Welding in the World, 56, 11-12 (2012)

11. K. Ichitani, M. Kanno, Sci. Tech. Adv. Mater, 4 (2003)

12. L. Starczewski, Wodorowe zużywanie ciernych elementów maszyn (Wojskowy Instytut Techniki Pancernej I Samochodowej, Sulejówek, 2002)

13. A. Zieliński, Niszczenie wodorowe metali nieżelaznych i ich stopów (Gdańskie Towarzystwo Naukowe, Gdańsk, 1999)

14. M. Sozańska, Niszczenie wodorowe typu "rybie oczy" wybranych stali dla energetyki

15. (Wyd. Politechniki Śląskiej, Gliwice, 2006)

16. J. Ćwiek, Ochr. przed kor 4-5 (2011)

17. H. Yashiro, P. Bound, N. Kumagai, K. Tanno, Corros. Sci, 40 (1998)

18. Y. Liu, M. Wang, G. Liu, Mater. Sci. Eng. A, 594 (2014)

19. J. Michalska, B. Chmiela, J. Łabanowski, W. Simka, J. Mater. Eng. Perform, 23, 8 (2014)

20. I. Pietkun-Greber, A. Mościcki, M. Sozańska, Proc. ECOpole 10, 1 (2016)

21. I. Pietkun-Greber, E3S Web of Conferences 19, 03007 (2017)

22. M. Szewd, W. Manaj, G. Wojas, J. Płowiec, T. Lusa, A Mech Automat, 1, 1 (2007)

23. PN-EN 10025-2. Wyroby walcowane na gorąco ze stali konstrukcyjnych. Część 2: Warunki techniczne dostawy stali konstrukcyjnych niestopowych

24. PN-EN ISO 6892-1. Próba rozciągania. Część 1: Metoda badania w temperaturze pokojowej 